\title{
8: 38153263-38187694
}

National Cancer Institute

\section{Source}

National Cancer Institute. 8: 38153263-38187694. NCI Thesaurus. Code C41740.

Physical location of BAG4_Gene 